\title{
BIOSPELEOLOGICAL NOTES ON FAUNA IN AN ARTIFICIAL CAVE IN PËRMET (ALBANIA) IMPORTANCE OF FORMER MILITARY INSTALLATIONS FOR BIODIVERSITY
}

\author{
Maria Naumova* \\ Institute of Biodiversity and Ecosystem Research, Bulgarian Academy of Sciences, 1 Tzar Osvoboditel Blvd., 1000 Sofia, Bulgaria \\ *Corresponding author. Email: munny@abv.bg
}

\begin{abstract}
Article history
Received: 1 January 2020;

accepted 16 April 2020
\end{abstract}

\section{Keywords:}

Bats; biodiversity hotspots; amphibians; spiders

\begin{abstract}
The subterranean fauna of both natural and artificial caves in Albania remains poorly studied. Cave colonisation can be clarified by investigating the same process in artificial underground sites. The existence of such a process can be judged by the composition of specific vertebrate and invertebrate species in every site. The biospeleological study carried out in an artificial cave in Përmet in June 2019 provided the following results: two bat species, i.e. Greater horseshoe bat Rhinolophus ferrumequinum (Schreber, 1774) and Mouse-eared bat Myotis myotis species group, probably M. blythii (Tomes, 1857) were observed, a specimen of the Balkan stream frog Rana graeca Boulenger, 1891, representing the first amphibian record for the Albanian cave, was discovered deep inside the cave, nine invertebrate species were found (7 spiders, 1 harvestman and 1 moth), with three of the spider species, i.e. Ceratinella brevis (Wider, 1834), Hogna radiata (Latreille, 1817) and Trachyzelotes barbatus (L. Koch, 1866), being the first records for Balkan caves. All recorded species, except Myotis blythii/myotis (both were previously known), are new to the study area. The total number of species recorded in this site, including the data available in literature, has increased to 29. This high number of species shows that artificial caves, including military installations, represent biodiversity hotspots, comparable to natural underground sites and demand much more attention and further investigations.
\end{abstract}

\section{INTRODUCTION}

Contemporary Albanian history includes the construction of thousands of military buildings, with tunnels and bunkers built between 1946 and 1990. These structures in Albania, just like those in other parts of the world, e.g. in North Korea, Atlantic wall, Verdun, where former military zones or buildings have become important reservoirs of biodiversity, host an interesting array of living organisms (Théou and Bego 2018).

Përmet is located in southern Albania, Gjirokastër County, near the border with Greece, in the largest Albanian national park "The Fir of Hotovë-Dangelli". This park encompasses a hilly and mountainous terrain composed of limestone and sandstone deposits, with numerous valleys, canyons, gorges, rivers and dense deciduous and coniferous forests. The International Union for Conservation of Nature (IUCN) has listed the park as Category II. From a geological point of view, the region of Përmet is part of the Ionian Structural-tectonic zone and is formed of Upper Jurassic to Eocene stratified limestone, siliceous limestone and siliceous rocks. Surface karst is not well developed; there are some sinkholes and small caves. The area is poorly exploited (Zhalov 2015).
During the previous speleological expedition to the region undertaken by B. Petrov, P. Stoev and S. Golovatch in 1995, 3 invertebrate species were detected (2 spiders and 1 millipede species) (Mauries et al. 1997; Deltshev et al. 2011; Zhalov 2015). In addition, a total of 15 bat species were previously known in the area, but without precise locations (Théou and Bego 2018).

The goal of the present study was to report new, more detailed biospeleological data about fauna in the artificial cave near Petran village, Përmet district, thereby contributing to the knowledge of the Albanian and Balkan cave dwellers in general, and supplementing the ecological data for some other species.

\section{MATERIALS AND METHODS}

Field investigations were carried out from 29 May to 6 June and the cave was visited on 4 June 2019. The invertebrate cave fauna was collected by hand, fixed in $70 \%$ ethanol and deposited in the collection of the Institute of Biodiversity and Ecosystem Research (Sofia), with the exception of moths, which were observed and photographed. Bats were not captured but photographed from a distance and their identification was made following the field guide of Dietz and von Helversen (2004). 
The nomenclature follows Stoev et al. (2008), Witt and Ronkay (2011), Schönhofer (2013), The World Spider Catalog (2019), Frost (2019), and Hutson et al. (2019). The taxa newly found in the cave are marked with an asterisk (*).Comments on the distribution of cave-dwelling spiders are in accordance with Deltshev (2008), Naumova et al. (2016a), and Mammola et al. (2019a, b), who have reported a total of 416 species for Balkan caves.

\section{Study area}

The object of the present study is an artificial military complex consisting of one transverse and two parallel galleries in the shape of the letter " $\mathrm{H}$ ", with a total of four entrances. Each of the three galleries is approximately $75 \mathrm{~m}$ long, with two eastern entrances being larger and positioned about 10 meters lower than the western ones. The deepest part of the cave is about 70-80 $\mathrm{m}$ away from each of the entrances. The military complex (Figure 1) is located east of Petran village, Përmet district in the Pindus mountain range, at geographical coordinates $\mathrm{N} 40.208883^{\circ}, \mathrm{E} 20.414827^{\circ}, 270 \mathrm{~m}$ a. s. 1. In Deltshev et al. (2011), the cave under investigation is referred to by number " 47 " and in Zhalov (2015) by number "18". Like other natural or artificial underground sites, the cave seems to provide a relatively cool and stable environment compared to that outside and could be also used by roosting bats and other animals.

\section{RESULTS}

A total of 12 species ( 7 spiders, 1 harvestman, 1 moth, 1 frog and 2 bats) were found. All of them, except the bats Myotis blythii/myotis are new to the region of Petran village as both M. blythii (Tomes, 1857) and M. myotis (Borkhausen, 1797) had been recorded there previously.
The total number of species for the cave, including the data available in literature, has increased to 29 .

\section{List of species \\ ARANEAE \\ *Agelenidae \\ *Maimuna vestita (C. L. Koch, 1841)}

New data: 1 , at one of the cave entrances, under a stone. Previously reported from a cave in Greece. No other cave reports from Europe. Reported from Albania (not in caves) by Caporiacco $(1932,1949)$ without location and by Vrenozi and Jäger (2012) from Tirana. Trogloxene.

\section{*Gnaphosidae \\ *Trachyzelotes barbatus (L. Koch, 1866)}

New data: 19 , under a stone, about $15 \mathrm{~m}$ deep in the cave. The first record in caves on the Balkan Peninsula. Reported for Albania by Deltshev et al. (2011), Vrenozi and Jäger (2012), Vrenozi and Deltshev (2012). Trogloxene.

\section{*Linyphiidae \\ *Ceratinella brevis (Wider, 1834)}

New data: 19 , at one of the cave entrances, under a stone. The first record in caves on the Balkan Peninsula. Reported for Albania from Bogë (North Albania) by Deltshev et al. (2011). Trogloxene.

*Lycosidae

*Hogna radiata (Latreille, 1817)

New data: 1 subadult 9 , at a depth of about $20 \mathrm{~m}$. The first record in caves on the Balkan Peninsula. The species is not a troglophile, but is likely to be found at cave entrances. Widespread in Europe but only four records had been reported for Albania before the current study

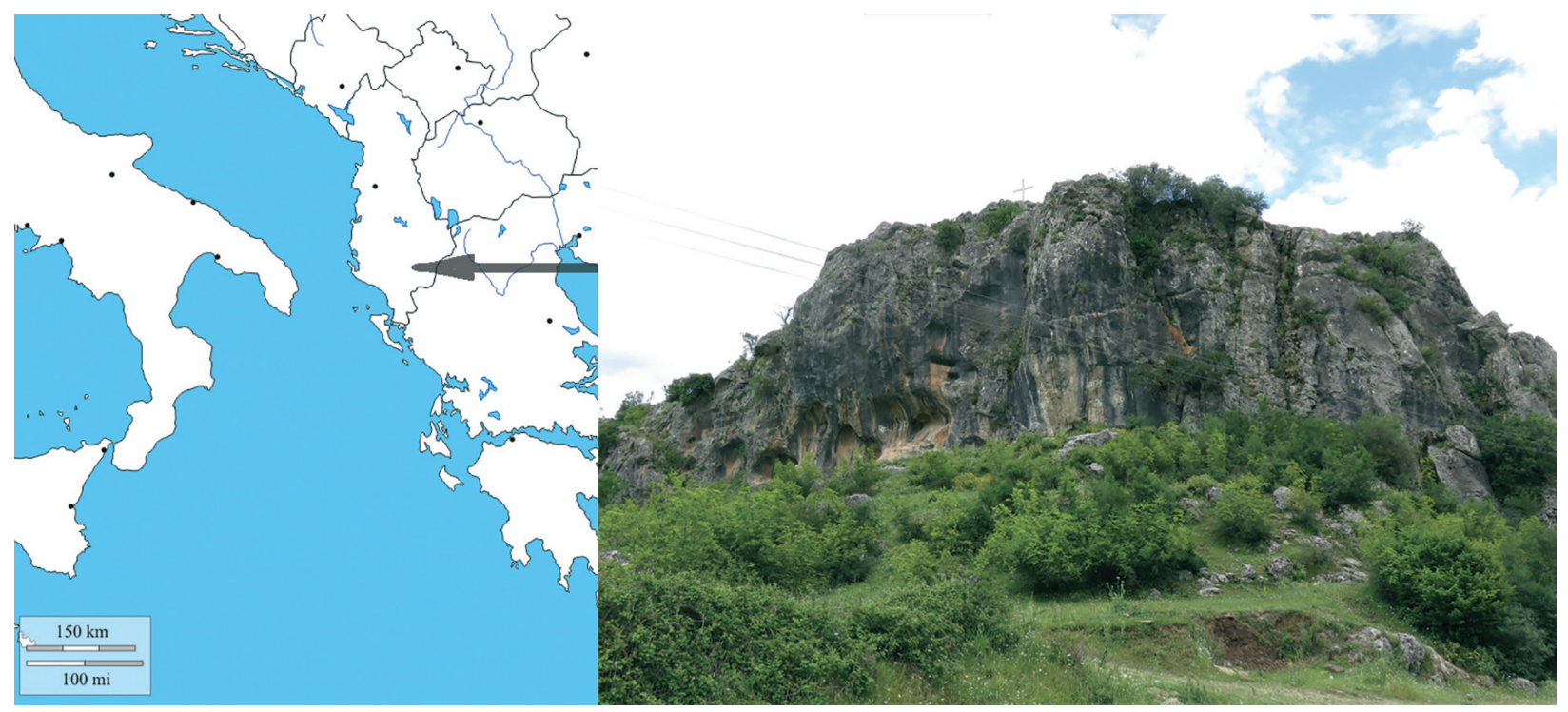

Figure 1. Cave location in South Albania and the karst formation where it is located. 
(Caporiacco 1932; Blagoev 2005; Naumova et al. 2016b; Naumova 2020). Trogloxene.

Pholcidae

Stygopholcus photophilus Senglet, 1971

Literature data: Deltshev et al. (2011). Troglobiont.

*Phrurulitidae

*Phrurolithus szilyi Herman, 1879

New data: $1 \hat{\jmath}$, under a stone, near the entrance. With a couple of previous records in Albania (Deltshev et al. 2011; Helsdingen van and IJuland 2015; Komnenov 2018; Kůrka et al. 2020), as well as one in Balkan caves (Deltshev et al. 2011). Trogloxene.

\section{* Scytodidae \\ * Scytodes thoracica Latreille, 1804}

New data: 19 , at one of the cave entrances, under a stone. Widespread within Europe, on a rocky littoral, under stones, mainly in buildings (Nentwig et al. 2019). Known from Balkan caves (Deltshev 2008), and also from Albania (Deltshev et al. 2011; Vrenozi and Jäger 2012; Kůrka et al. 2020). Trogloxene.

*Tetragnathidae

* Metellina merianae (Scopoli, 1763)

New data: 1 subadult 9,2 juveniles, on the walls. Widespread within Europe in subterranean habitats. Reported for Albania from artificial galleries near Petrela and near Pustes and from natural caves near Dhërmi and near Borova (Deltshev et al. 2011) and also from two caves in Lurë Mts. (Dundarova et al. 2018). Troglophile.

Theridiidae

Steatoda triangulosa (Walckenaer, 1802)

Literature data: Deltshev et al. (2011). Trogloxene.

\section{*OPILIONES}

*Phalangiidae

*Lacinius horridus (Panzer, 1794)

New data: 1 juvenile, on the floor, about $40 \mathrm{~m}$ inwards from the cave entrance. Trogloxene.

\section{DIPLOPODA}

Schizopetalidae

Acanthopetalum (Petalysium) carinatum (Brandt, 1840)

Literature data: Mauries et al. (1997), Deltshev et al. (2011). Trogloxene.

\section{INSECTA}

*LEPIDOPTERA

*Noctuidae

* Amphipyra effusa Boisduval, 1828
New data: 3 specimens, observed and photographed (Figure 2) about 40-60 m deep in the cave. The species is distributed from Northwest Africa across the Mediterranean and in the warmer parts of Asia. The caterpillars become mature in April or May. The moths fly from May until the autumn/winter and estivate in the hot summer months. They are reported to rest in caves (Beshkov and Petrov 1996; Beshkov and Wegner 2004; Beron et al. 2004; Beron 2015). Trogloxene.

\section{*AMPHIBIA \\ *ANURA \\ *Ranidae \\ *Rana graeca Boulenger, 1891}

New data: one adult specimen (Figure 3), observed about $60 \mathrm{~m}$ deep in the cave, in the transverse wet gal-

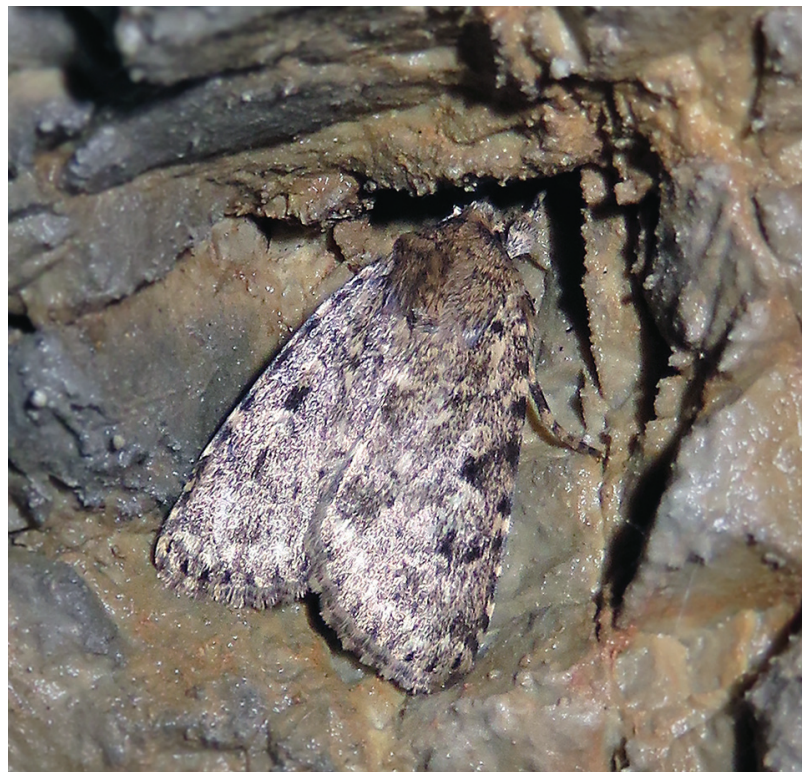

Figure 2. Noctuid moth Amphipyra effusa.

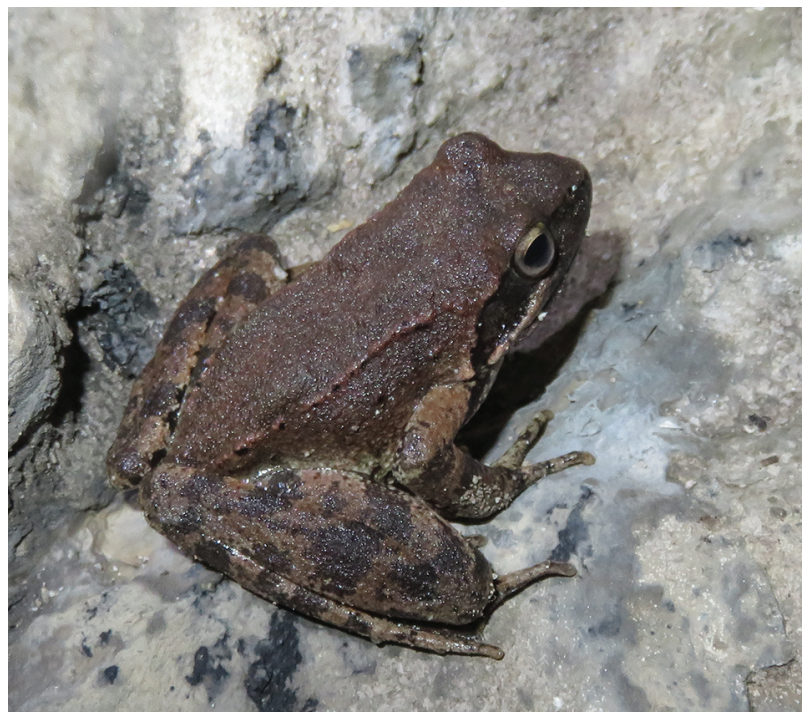

Figure 3. Balkan stream frog (Rana graeca). 


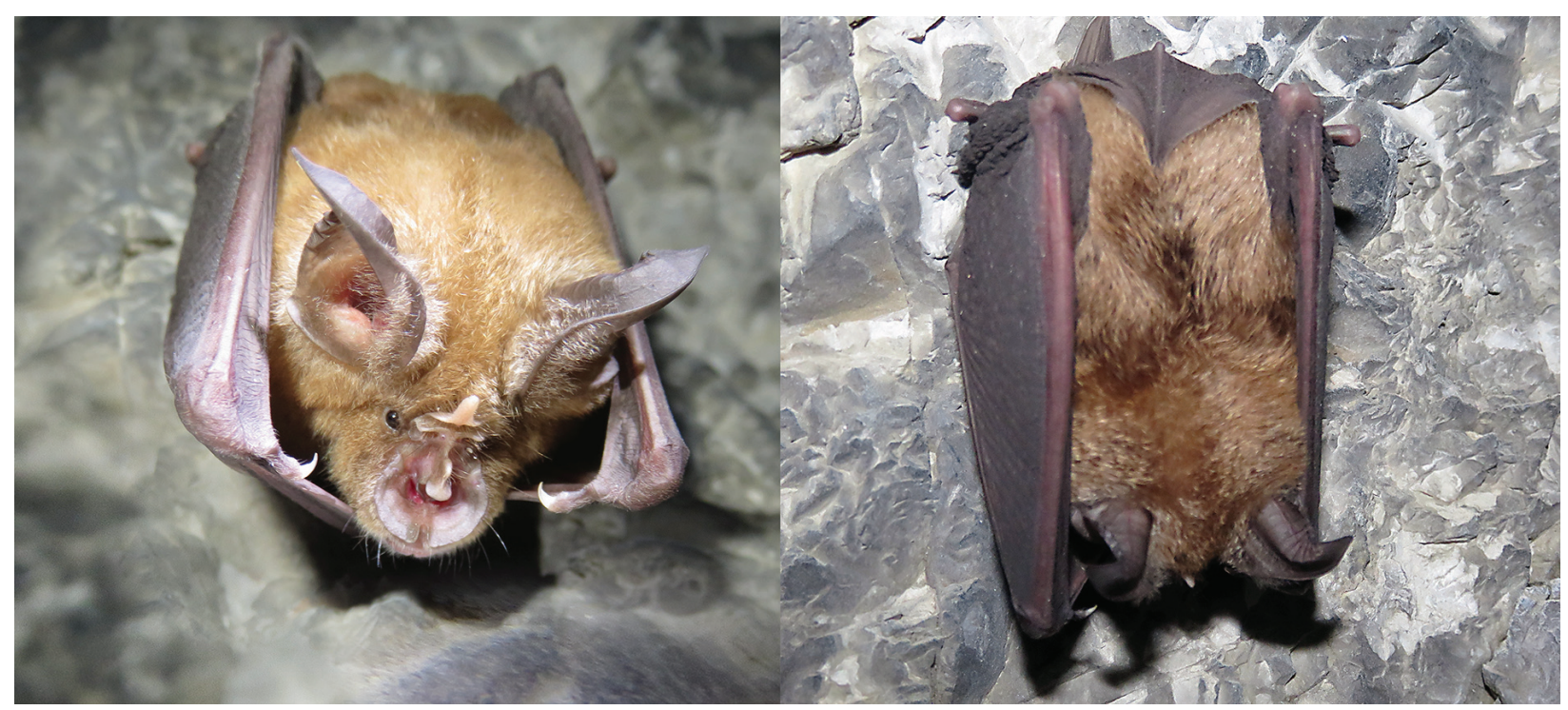

Figure 4. Greater horseshoe bat (Rhinolophus ferrumequinum).

lery. This is the first record of this species deeper from the cave entrance. Least Concern (IUCN 2019).

\section{MAMMALIA \\ CHIROPTERA \\ Rhinolophidae}

Rhinolophus blasii Peters, 1866

Literature data: Théou and Bego (2018). Least Concern (IUCN 2019).

R. euryale Blasius, 1853

Literature data: Théou and Bego (2018). Near Threatened (IUCN 2019).

*R. ferrumequinum (Schreber, 1774)

New data: 2 single specimens (Figure 4) recorded separately about 40-60 $\mathrm{m}$ deep in the cave. Least Concern (IUCN 2019).

R. hipposiderus Bechstein, 1800

Literature data: Théou and Bego (2018). Least Concern (IUCN 2019).

\section{Vespertilionidae}

Eptesicus serotinus (Schreber, 1774)

Literature data: Théou and Bego (2018). Least Concern (IUCN 2019).

Hypsugo savii (Bonaparte, 1837)

Literature data: Théou and Bego (2018). Least Concern (IUCN 2019).

Miniopterus schreibersii (Kuhl, 1817)

Literature data: Théou and Bego (2018). Near Threatened (IUCN 2019).

Myotis bechsteinii (Kuhl, 1817)

Literature data: Théou and Bego (2018). Near Threatened (IUCN 2019).

Myotis blythii (Tomes, 1857)

Literature data: Théou and Bego (2018). Least Concern (IUCN 2019).

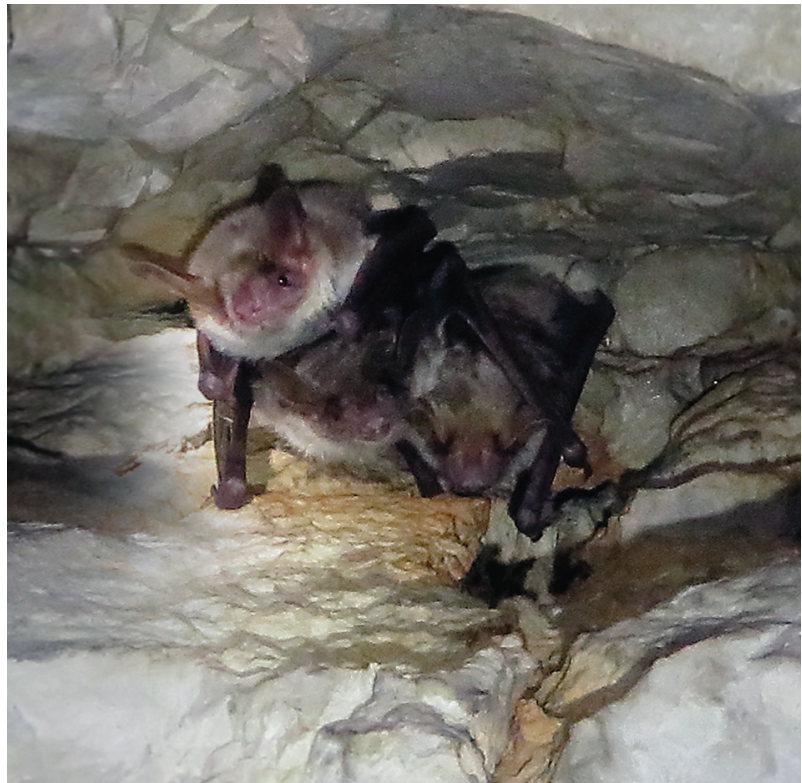

Figure 5. Mouse-eared bat (Myotis species group).

\section{M. blythii/myotis}

New data: 3 specimens deep in the cave, in a group (Figure 5).

M. emarginatus Geoffroy, 1806

Literature data: Théou and Bego (2018). Least Concern (IUCN 2019).

M. myotis (Borkhausen, 1797)

Literature data: Théou and Bego (2018). Least Concern (IUCN 2019).

M. mystacinus Kuhl, 1817

Literature data: Théou and Bego (2018). Least Concern (IUCN 2019).

M. nattereri Kuhl, 1817

Literature data: Théou and Bego (2018). Least Concern (IUCN 2019). 
Nyctalus noctula Schreber, 1774

Literature data: Théou and Bego (2018). Least Concern (IUCN 2019).

Pipistrellus kuhlii Kuhl, 1817

Literature data: Théou and Bego (2018). Least Concern (IUCN 2019).

P. pipistrellus Schreber, 1774

Literature data: Théou and Bego (2018). Least Concern (IUCN 2019).

\section{DISCUSSION}

Out of the 51 species recorded in Europe (Hutson et al. 2019), 32 bat species are known to occur in Albania (Théou and Bego 2018), two of which were recorded during this visit to the artificial cave. Both bat species use caves for the summer roost. The greater horseshoe bat Rhinolophus ferrumequinum is one of the two targeted bat species of the Pan-European Biological and Landscape Diversity Strategy (Ransome and Hutson 2000). Until now, there have been no data about the presence of amphibians in Albanian caves. In general, information on the repose and summer roost of frogs in European caves is scarce. The only recent detailed overview of the herpetological fauna covers karst cavities of the Crimean Mountains (Turbanov et al. 2019). Sightings of $R$. graeca were reported only from entrances to three caves in Bulgaria (Western Rhodopes Mts.: entrances to Uhlovitsa and Gargina Dupka caves near Mostovo village, and the entrance to the mine gallery at Dzurkovo village) (Petrov et al. 2006). There are only a few reports on sightings of its closest congener $R$. dalmatina Fitzinger, 1838, also, from Bulgaria (the cave Svardelo pothole near Lakatnik Railway Station (Beron 2015), and entrances to Topchika (Beshkov 1972), and Snezhanka caves (Petrov et al. 2006), both in Western Rhodopes Mts).

In total, there were nine trogloxenes, one troglophile and one troglobiont invertebrates recorded. Most of the recorded invertebrate species are typical of Balkan caves (Beron 2015), but three spider species have been recorded therein for the first time, thus increasing their number up to 419 species. The presence of troglobiont and troglophile species in an artificial object (with appropriate characteristics) is interesting and shows that colonisation of an artificial underground installation is similar to that of a natural site. The primary aim of biospeleological research is protection of underground habitats and organisms. The knowledge of species composition and representation of interesting, rare, threatened and protected species, including monitoring and protection of bats, are well known priorities, but the investigation into artificial underground sites is still given insufficient attention. The subterranean fauna in Albania, both in natural and man-made caves, is still poorly studied and further investigations are extremely necessary.

\section{ACKNOWLEDGEMENTS}

I would like to thank Dr Povilas Ivinskis and Dr Jolanta Rimšaite (Nature Research Centre, Vilnius) for their helpful comments and Ms. Laima Monkiene for the linguistic revision of the manuscript.

\section{REFERENCES}

Beron, P. 2015. Cave fauna of Bulgaria. East-west publishing.

Beron, P., B. Petrov, and P. Stoev. 2004. The invertebrate cave fauna of the Eastern Rhodopes (Bulgaria and Greece). In Biodiversity of Bulgaria. 2. Biodiversity of Eastern Rhodopes (Bulgaria and Greece), edited by P. Beron and A. Popov, 791-822. Sofia: Pensoft and National Museum of Natural History.

Beshkov, V. 1972. Zwischenartenkontakte und Zusammenleben der Frösche in Bulgarien. Bulletin de l'Institut de Zoologie et Musée, Sofia 34: 85-95 (In Bulgarian).

Beshkov, S., and B. Petrov. 1996. A Catalogue of the Bulgarian Lepidoptera species reported and collected from the caves and galleries in Bulgaria (Insecta: Lepidoptera). Atalanta 27 (1/2): 433-448.

Beshkov, S., and H. Wegner. 2004. Macrolepidoptera of the Greek part of the Eastern Rhodopes. In Biodiversity of Bulgaria. 2. Biodiversity of Eastern Rhodopes (Bulgaria and Greece), edited by P. Beron and A. Popov, 677-722. Sofia: Pensoft and National Museum of Natural History.

Blagoev, G. 2005. A contribution to the knowledge of the wolf spiders (Araneae: Lycosidae) of Albania. Acta zoologica bulgarica 57: 139-144.

Caporiacco, L. di. 1932. Aracnidi raccolti in Albania dal dott. Pietro Parenzan. Atti dell'Accademia VenetoTrentino-Istriana 23: 93-98.

Caporiacco, L. di. 1949. Alcuni aracnidi albanesi. Atti del Museo Civico di Storia Naturale di Trieste 17: 122-125.

Deltshev, C. 2008. Faunistic diversity and zoogeography of cave-dwelling spiders on the Balkan Peninsula. In Advances in Arachnology and Developmental Biology. Papers dedicated to Prof. Dr. Božidar Ćurčić, edited by S. E. Makarov, and R. N. Dimitrijevic, 327-348. Vienna-Belgrade-Sofia, Monographs 12: Belgrade: Institute of Zoology, Sofia: BAS, Vienna: Faculty of Life Sciences, Belgrade: SASA and UNESCO MAB Committee, Serbia.

Deltshev, C., B. Vrenozi, G. Blagoev, and S. Lazarov. 2011. Spiders of Albania - Faunistic and Zoogeographical Review (Arachnida: Araneae). Acta zoologica bulgarica 63 (2): 125-144.

Dietz, C., and O. von. Helversen. 2004. Illustrated identifcation key to the bats of Europe. Electronic Publication. 
https://auvergne-rhone-alpes.lpo.fr/images/chiroptere/ telecharger/dietz_von_helversen_2004_1.pdf. 35 p.

Dundarova, H., I. Dedov, T. Ljubomirov, A. Zhalov, and C. Deltshev. 2018. Preliminary research on the cave fauna in three caves in Lurë Mountain (Albania). $8 t$ th Symposium on karst protection-proceedings, 139-144. Belgrade: Student Speleological and Alpinistic Club.

Frost, D. R. 2019. Amphibian Species of the World: an Online Reference. Version 6.0. Electronic Database. http://research.amnh.org/herpetology/amphibia/index. html. American Museum of Natural History, New York, USA. on $24 / 11 / 2019$.

Helsdingen, P. J. van, and S. IJland. 2015. A quick scan of the spider fauna in the surroundings of Përmet, Albania (Arachnida, Araneae). Preliminary report. Nieuwsbrief Spinnenwerkgroep Nederland 35: 15-33.

Hutson, A. M., F. Marnell, and R. Petermann. 2019. A guide to the implementation of the Agreement on the Conservation of Populations of European Bats (EUROBATS). Version 2. UNEP/EUROBATS Secretariat, Bonn, Germany.

IUCN. 2019. The IUCN Red List of Threatened Species. Version 2019-2. https://www.iucnredlist.org. on 24/11/2019.

Komnenov, M. 2018. Spiders (Arachnida: Araneae) of the floodplains of the Vjosa river, south Albania. Acta ZooBot Austria 155: 197-212.

Kůrka, A., M. Naumova, S. Indzhov, and C. Deltshev. 2020. New faunistic and taxonomic data on the spider fauna of Albania (Arachnida: Araneae). Arachnologische mitteilungen 59 (1): 8-21.

Mammola, S., P. Cardoso, D. Angyal, G. Balázs, T. Blick, H. Brustel, J. Carter, S. Ćurčić, S. Danflous, L. Dányi, S. Déjean, C. Deltshev, M. Elverici, J. Fernández, F. Gasparo, M. Komnenov, C. Komposch, L. Kováč, K. B. Kunt, A. Mock, O. Moldovan, M. Naumova, M. Pavlek, C. E. Prieto, C. Ribera, R. Rozwałka, V. Růžička, R. S. Vargovitsh, S. Zaenker, and M. Isaia. 2019a. Continental data on cave-dwelling spider communities across Europe (Arachnida: Araneae). Biodiversity Data Journal 7, e38492. doi:10.3897/ BDJ.7.e38492. https://doi.org/10.3897/BDJ.7.e38492

Mammola, S., P. Cardoso, D. Angyal, G. Balázs, T. Blick, H. Brustel, J. Carter, S. Ćurčić, S. Danflous, L. Dányi, S. Déjean, C. Deltshev, M. Elverici, J. Fernández, F. Gasparo, M. Komnenov, C. Komposch, L. Kováč, K. B. Kunt, A. Mock, O. Moldovan, M. Naumova, M. Pavlek, C. E. Prieto, C. Ribera, R. Rozwałka, V. Růžička, R. S. Vargovitsh, S. Zaenker, and M. Isaia. 2019b. Local versus broad scale environmental drivers of continental beta diversity. Proceedings of the Royal Society B: Biological Sciences 286 (20191579): 1-9. https://doi.org/10.3897/BDJ.7.e38492.figure1

Mauries, J. P., S. I. Golovatch, and P. Stoev. 1997. The millipedes of Albania: recent data, new taxa; systematical, nomenclatural and faunistical review (Myriapoda, Diplopoda). Zoosystema 19 (2-3): 255-292.

Naumova, M. 2020. Description of two new spider species with new data for the Albanian arachnofauna (Arachnida: Araneae, Opiliones, Pseudoscorpiones \& Scorpiones). Acta zoologica bulgarica 72 (1): 3-12.

Naumova, M., S. Lazarov, B. Petrov, and C. Deltshev. 2016a. New faunistic data on the cave-dwelling spiders in the Balkan Peninsula (Araneae). Ecologica Montenegrina 7: 425-438.

Naumova, M., S. Hristovski, and G. Hristov. 2016b. Spiders (Arachnida: Araneae) from Prespa National Park, Albania. Acta zoologica bulgarica 68 (4): 503-511.

Nentwig, W., T. Blick, R. Bosmans, D. Gloor, A. Hänggi, and C. Kropf. 2019. Araneae. Version $\{11\} .2019$. https://www.araneae.nmbe.ch. on 24/11/2019.

Petrov, B., N. Tzankov, H. Strijbosh, G. Popgeorgiev, and V. Beshkov. 2006. The herpetofauna (Amphibia and Reptilia) of the Western Rhodopes mountain (Bulgaria and Greece). In Biodiversity of Western Rhodopes (Bulgaria and Greece), edited by P. Beron, 863-912. Sofia: Pensoft.

Ransome, R. D., and A. M. Hutson. 2000. Action plan for the conservation of the greater horseshoe bat in Europe (Rhinolophus ferrumequinum). Nature and Environment: 109. Strasbourg: Council of Europe.

Schönhofer, A. L. 2013. A Taxonomic Catalogue of the Dyspnoi Hansen and Sørensen, 1904 (Arachnida: Opiliones). Zootaxa 3679 (1): 1-68. https://doi. org/10.11646/zootaxa.3679.1.1

Stoev, P., P. Sierwald, and A. Billey. 2008. An annotated world catalogue of the millipede order Callipodida (Arthropoda: Diplopoda). Zootaxa 1706: 1-50. https:// doi.org/10.11646/zootaxa.1706.1.1

Théou, B., and F. Bego. 2018. Atlas of Bats in Albania. NaturAl project.

Turbanov, I. S., O. V. Kukushkuin, and R. S. Vargovitsh. 2019. Amphibians and reptiles in the subterranean cavities of the Crimean Mountains. Russian Journal of Herpetology 26 (1): 29-53.

Vrenozi, B., and C. Deltshev. 2012. Spiders (Araneae) from Vora hills, Albania. Albanian Journal of Agricultural Sciences 11: 179-183.

Vrenozi, B., and P. Jäger. 2012. Faunistic study on grounddwelling spiders (Araneae) in the Tirana district, Albania. Arachnologische Mitteilungen 44: 81-87. https:// doi.org/10.5431/aramit4412

Witt, T. J., and L. Ronkay (eds). 2011. Noctuidae Europaeae. Vol. 13, Lymantriinae and Arctiinae including phylogeny and check list of the quadrifid Noctuoidea of Europe. Sorø: Entomological Press.

World Spider Catalog. 2019. World Spider Catalog. Version 20.5. Natural History Museum Bern. http://wsc.nmbe. ch. on 24/11/2019.

Zhalov, A. 2015. Bulgarian speleological studies in Albania 1991-2013. Berliner Hölenlenkundlich berichte. 